\title{
EUROPEAN UNION INTERNAL MARKET AND ITS BARRIERS: MISSION ACCOMPLISHED OR NEVER ENDING STORY?
}

\author{
Silvia RUČINSKÁ, PhD \\ Associate Professor, Pavol Jozef Šafárik University Košice, Faculty of Public Administration, \\ Slovakia \\ silvia.rucinska@upjs.sk \\ Miroslav FEČKO, PhD \\ Pavol Jozef Šafárik University Košice, Faculty of Public Administration, Slovakia \\ $\underline{\text { miroslav.fecko@upjs.sk }}$
}

\begin{abstract}
This article refers to the progress and limitations of the European Union Internal Market at present. More than thirty years after the Single European Act, sixty years after the Treaties of Rome, in relation to a questionable future widening and deepening of integration in the European Union, and given the still unclear current conditions and consequences of Brexit, as well as facing the ongoing migration movements, the internal market is also today a current public policy, economic, social and real-life issue. A lot of progress towards a functioning internal market has been reached, but still unsolved issues, obstacles and barriers limiting the potential of a market consisting of all EU Member States remain. A precondition to mitigate and remove obstacles is the identification of barriers to the entire European Union Internal Market and in particular their specification to the free movement of goods, services, capital and persons. This article aims to provide a very complex view onto the European Union Internal Market and onto the currently most manifesting barriers of the European Union Internal Market and of the barriers within the economic freedoms.
\end{abstract}

Keywords: European Union, Integration, Internal Market, Barriers.

\section{Introduction}

Economic integration in Europe was after World War II an important and main element, a common motive determining the formation of the European Union (EU) up to its present form. In 
this regard, the EU Internal Market as the most developed and sophisticated economic integration project (Howarth and Sadeh, 2010) represented a 'cornerstone of European integration' (Egan and Guimarăes, 2012, p. 1) and created necessary foundations for EU Member States' integration also in other areas. The EU nowadays represents more than an economic cooperation or cooperation taking only economic benefits into account.

Up until 2016, the EU integration process was accompanied by a parallel enlargement and deepening of integration (Kelemen, Menon and Slapin, 2014) and for the first time in history the EU today is facing a process which is reverse in relation to what we have known so far. The disintegration of the EU (Patomäki, 2017), leaving the EU (Bachmann and Sidaway, 2016), exit from the EU (Welfens, 2016), withdrawal from the EU (Pain and Young 2004) can be used as significant naming of this process. From the point of the EU Internal Market, the events preceding and following the voting of Great Britain leaving the EU once more raised the need to deal with questions about EU integrity and functioning of its internal market. In this article the attention won't be focused on Brexit consequences regarding the EU Internal Market. However the EU Internal Market problematic is as pertinent today as in the past it was.

Rueda-Cantuche et al. (2013) highlighted the importance of the EU Internal Market and of the European integration in the context of employment creation in the EU, by pointing out a faster economic growth of open economies. According to Egan and Guimarăes (2012) the EU Internal Market has to be considered not only as a fulfilment of the EU primary law obligations, but also as a key factor for entrepreneurship, growth and employment by supporting the competitiveness. Functioning EU Internal Market is particularly important for those businesses, trading across borders (Guimarães and Egan, 2014). A common space between the EU Member States (Kostadinova, 2013), in the form of the EU Internal Market significantly helps to attain economic growth within the EU (Badinger, 2005) and to create jobs and to increase employment (RuedaCantuche et al., 2013). Despite its importance, there are still deficiencies of the EU Internal Market. Pelkmans and Mustilli (2014) confirmed existing EU Internal Market's deficiencies and in this regard they stated that a minimization of these deficiencies would result in additional GDP growth in the EU and in the individual EU Member States' economies. Siim Kallas as a European Commission Commissionaire for Transport and a Vice-president of the European Commission in 2010-14 in this regard noted, that one of the best ways to boost economic growth is the removal of barriers in the EU Internal Market (European Commission, 2015i). 
Based on the importance of the EU's Internal Market - even though its implementation remains incomplete -, the goal of this article is to provide a complex identification and analysis of still existing barriers to the entire EU Internal Market and barriers to the free movement of goods, services, capital and persons. The completion of the EU Internal Market is hindered by existing obstacles. Based on the complexity of the EU Internal Market the assumption is that the same complexity and heterogeneity will also characterize the barriers itself. Regarding the barriers, it is also necessary to analyse, whether the barriers are the same between the four economic freedoms or whether the character and type of the barriers differs in relation to a concrete economic freedom. The approach in this article aims to be cross cutting and taking into consideration the entire EU Internal Market and all economic freedoms. Our analysis is based on the EU Internal Market consisting of 28 Member States, before the negotiations about the conditions of Great Britain leaving the EU started.

The article is divided into three main sections. In the first section the EU Internal Market is analysed as an uncompleted project. The second section is dedicated to an identification and characteristic of today's existing barriers to the entire EU Internal Market and of the barriers to the free movement of goods, services, capital and persons, which hinder and limit the EU Internal Market's completion. The third part analyses the terminological and content definition of the EU Internal Market and the resulting recommendations.

\section{Uncompleted European Union Internal Market}

The Treaty on EU enshrined the EU Internal Market in article 3, section 3, where it is stated, that 'the Union shall establish an internal market'. Another mentions, closer characteristics and concretization of the EU Internal Market are covered by the Treaty on the Functioning of the EU. In article 3, section 1 of the Treaty on the Functioning of the EU is the EU Internal Market mentioned in relation with the exclusive EU competences and the need for adopting necessary competition rules. Subsequently, according to article 4, section 2 of the Treaty on the Functioning of the EU the EU Internal Market is defined as one of the areas, where the shared competences of the EU and the EU Member States are applied. Part three, title one of the Treaty on the Functioning of the EU is dedicated especially to the EU Internal Market, which is according to article 26, section 2 understood as an 'area without internal frontiers in which the free movement of goods, persons, services and capital is ensured in accordance with the provisions of the Treaties'. Also 
other provisions of the Treaty on the Functioning of the EU, as for example article 115, article 116, article 118, article 134, are dealing with the EU Internal Market in terms of a legislative, institutional and political ensuring and supporting of its functioning. Free movement of goods, services, capital and persons, as the four economic freedoms capture the essence and characteristics of the EU Internal Market.

Free movement of goods, services, capital and persons as economic freedoms of the EU Internal Market are interconnected. In this sense, for example the free movement of services is possible only if the free movement of persons is also ensured at the same time, in relation to the services consumer and services provider and the free movement of capital, in the form of crossborder movement of capital as of the foreign direct investment. Economic freedoms of the EU Internal Market are not applied individually and each independently, but all four together in mutual interaction.

The liberalization of the free movement of goods, services, capital and persons had not taken place just as fast and achieved accomplishments in each economic freedoms were not equal. According to the European Commission (2012) the market integration in goods, despite its slower pace is still progressing, as there are EU Member States with a higher and EU Member States with a lower level of integration in this area, given the development of the intra-EU imports and exports in goods to GDP. The European Commission (2012c) when comparing the trade in services with the trade in goods had stated that in long-term perspective the trade in services is characterized by a lower integration level. Lower integration level and a slower liberalization in services sector comparing to other economic freedoms was confirmed also by Levent (2009). Despite this fact, the entire EU has, thanks to the free movement of services in the EU Internal Market, a dominant position on the global services market (Kerneis and Prentice, 2011). In regards to the free movement of persons, as being a fundamental component of the EU Internal Market (Carrera, 2005; Răvaş, 2009; van Riemsdijk, 2013), the migration between the EU Member States remains at a low level (Bluj, 2008). Labour mobility in the EU is substantially lower than its potential in the EU Internal Market, as the economically active EU population working in another EU Member State accounts for only 3.1 per cent of the EU workforce (European Commission, 2012). European Commission (2012) underlined the importance of the free movement of capital being a key integration factor and as of a necessary prerequisite for investments and innovations. At the same time when referring to the effects of the global economic crisis the European Commission (2012) 
highlighted, that changes in the finance sector of the individual EU Member States is essential to coordinate, because the opposite - no coordination - could jeopardize the economic integration and limit the benefits resulting from the European financial integration.

The history of the European integration process, particularly of the EU Internal Market formation has shown that the EU Internal Market is in an ongoing process, which is accompanied by elimination of the existing barriers to the free movement of goods, services, capital and persons. The perception of the EU Internal Market as of a process was in different contexts highlighted for example by Palmer (1989), Cherchye et al. (2007), Howarth and Sadeh (2010), Egan and Guimarăes (2012). Already Palmer (1989) drew attention to a gradual establishment of the EU Internal Market and to a fact, that it's impossible to predict its completion. Cherchye et al. (2007) characterized the EU Internal Market as an ongoing process of four economic freedom's implementation. According to Howarth and Sadeh (2010) the EU Internal Market is an unfinished project, which completion can be difficult to predict and which is moreover constantly reinterpreting and supplementing with new goals. EU Internal Market as a project was characterized also by Egan and Guimarăes (2012), who as the reasons for an unfinished EU Internal Market stated mainly continuing protectionist tendencies of the EU Member States and non-compliance with uniform rules.

Unfinished and uncompleted EU Internal Market was characterized also by Knudsen (2005), Canoy and Smith (2008), Arnold and Wörgötter (2011), König and Ohr (2013). According to Knudsen (2005) is the existence of the EU Internal Market only an appearance and because of existing barriers there can't be a functioning EU Internal Market. Canoy and Smith (2008) assumed that the EU Internal Market can never be completed, because of the dynamic character of markets. Arnold and Wörgötter (2011) came to a conclusion, that the completion of the EU Internal Market takes place at an uneven pace. Similarly König and Ohr (2013) claimed that the economic integration in the EU is in the individual EU Member States at different levels, based on differences between the integrated countries. Although Wagner (2015) has noted the creation of the EU Internal Market, in his research focused on posting of workers to another EU Member States he pointed out the changing character and formation of new borders between the EU Member States. Polanski (2015) has also used a statement about a completed EU Internal Market, but at the same time he analysed and highlighted the existence of electronic barriers and an uncompleted Digital Single Market. 
With regards to the trade conditions of businesses in the EU Internal Market, Guimarăes and Egan (2014) identified the free movement of goods as the most integrated and successful EU Internal Market's economic freedom, although despite this statement they indicated in this area remaining obstacles and deficiencies. Hafner, Robin and Hoorens (2014) also stressed, that obstacles and barriers hindering the free movement of goods in the EU Internal Market currently still exist, but they also stated, that the barriers to the free movement of goods are smaller than the barriers to the free movement of services.

Incompletion and dysfunction of the EU Internal Market, concretized regarding the free movement of services also appeared in the topical literature (Aidukiene and Kazlauskiene, 2012; Badinger and Maydell, 2009; Canoy and Smith, 2008; Howarth and Sadeh, 2010; Jacobsson, 2013; Kerneis and Prentice, 2011; Pelkmans and Mustilli, 2014). Badinger and Maydell (2009) but also Aidukiene and Kazlauskiene (2012) pointed out the incompletion of the services in the internal market in the context of the adoption of the Directive 2006/123/EC of the European Parliament and of the Council of 12 December 2006 on services in the internal market (Services Directive). Here ist was characterized as an important tool for completion of the EU Internal Market in services. Jacobsson (2013) noted the EU Internal Market in services as uncompleted and characterized by the heterogeneity of the EU Member State's policies. Canoy and Smith (2008) stated the incompletion of the services internal market based on the heterogeneity of services itself, which makes the internal market in services complex and difficult to unify. Kerneis and Prentice (2011) highlighted the EU Internal Market in services only as seemingly well-functioning, in which still many barriers exist though. Pelkmans and Mustilli (2014) described the EU Internal Market in services as dysfunctional, where still possibilities for its deepening, improvement of its good functioning and elimination of existing gaps and shortcomings remain. Howarth and Sadeh (2010) in relation to services in the EU Internal Market reminded that despite the importance of services, the achieved progress in liberalization of services was small, especially in comparison to the industrial goods.

According to Badinger and Maydell (2009) but also based on Egan and Guimarăes (2012), the integration of services lags behind the integration of goods, despite the high share of services in GDP. Canoy and Smith (2008) building on the statements about a further reaching integration in goods compared to services indicated, that the integration in services will take longer. Pelkmans (2012) comparing the integration of the free movement of goods and the free movement of services 
has also stated, that the integration in services has always lagged behind the deepening of the EU Internal Market in goods and that it was less extensive and less firm. Arnold and Wörgötter (2011) have recalled the differences in integration of goods and services, where on the one side they highlighted the progress within the free movement of goods and mutual recognition of standards, and on the other side they stressed the relatively little progress in the services sector and in the mutual recognition of qualifications with the connection of services and of the free movement of persons.

In relation to the free movement of capital, Jonathan Hill as a representative of the European Commission responsible for the financial stability, financial services and the union of capital markets has noted, that the EU Internal Market even today isn't still fully functioning (European Commission 2015g). Pungulescu (2013) stated a still ongoing process of capital market's integration and the lack of the free movement of capital in the EU Internal Market. Bartz and Fuchs-Schündeln (2012) confirmed that the internal market is uncompleted also in relation to the free movement of persons. According to Martinoia (2011) the free movement of persons remains a problem of the EU integration process, as evidenced by the low internal migration between the EU Member States.

Juncker (2014) when introducing his plans as of a candidate for the President of the European Commission 15th July 2014 in Strasbourg has identified the EU Internal Market and the necessity to complete the internal market in goods and services as one of his priorities. The EU Internal Market remains uncompleted as a whole but also partially within the free movement of goods, services, capital and persons.

\section{Barriers to the EU Internal Market}

An uncompleted EU Internal Market and its understanding as a process means, that there are obstacles hindering the completion of this process. These obstacles have the character of barriers, which are barriers to the entire EU Internal Market and barriers to the free movement of goods, services, capital and persons in the EU Internal Market. Even today 'barriers to a true single market remain plentiful' (Guimarăes and Egan, 2014, p. 25).

Legal barriers to the EU Internal Market are manifested in the form of missing legislation acts where necessary, non-transposition of legislation regulations regarding the various components of the EU Internal Market, incorrect transposition of the EU Internal Market 
legislation or in the form of a delayed transposition of the EU Internal Market legislation. These legal barriers were according to the July 2016 edition of the Single Market Scoreboard (European Commission, 2016g) characterized through:

- transposition deficit, which amounted 0.7 per cent in EU average, what means that 0.7 per cent of all legislation acts have not been transposed into the national legislation. Each EU Member State has had the transposition deficit and thus each EU Member State haven't transposed some part of the EU Internal Market legislation.

- $\quad$ compliance deficit, which amounted 0.7 per cent in EU average and each of the EU Member States had to some extend a compliance deficit. This highlights the inconsistency of the transposition processes in the EU Member States, because 0.7 per cent of all legislation acts regarding the EU Internal Market were transposed incorrectly and infringement procedures were launched.

- Number of long overdue directives, with transposition deadlines more than two years past. Altogether 10 EU Member States had such directives, with Austria (three directives), France (two directives) and the Netherlands (two directives) to name the three worst EU Member States in this regard.

- transposition delay, which indicates the delay in transposition for overdue directives in months. EU Member States were in average 10.1 months delayed and each one of the EU Member States had a transposition delay.

Indicators analysed through the Single Market Scoreboard identified, that the nature of the legal barriers to the EU Internal Market is not only the lack of legislation acts, as of an important tool for ensuring the conditions for realization of all four economic freedoms, but also inconsistency of the EU Member States.

Legal barriers remain and new ones appear in all economic freedoms. According to the 2014 and 2015 Annual reports of the Court of Justice of the EU (Court of Justice of the European Union, 2015; Court of Justice of the European Union, 2016) new cases were reported regarding the free movement of goods (11 cases in 2014 and eight cases in 2015), freedom to provide services (19 cases in 2014 and 24 cases in 2015), freedom of establishment (26 cases in 2014 and 12 cases in 2015), free movement of capital (seven cases in 2014 and six cases in 2015) and freedom of movement for persons (11 cases in 2014 and 15 cases in 2015). 
Terták (2010) indicated fiscal barriers as the barriers to the EU Internal Market, and this related to the little EU competences in the area of taxation, while some progress has been already made in the application of non-discriminatory taxation. According to Howarth and Sadeh (2010) the EU Internal Market will remain uncompleted, unless there is a unified taxation system. But given the traditionally national fiscal policy and taxation competences, the EU Member States will remain restrained in terms of harmonization progress. Fiscal harmonization is 'as necessary as it is desirable' (Trandafir, 2013, p. 647) and in particular the world economic crisis highlighted the importance for a responsible fiscal policy by the EU Member States. But the EU Member States' governments already based on the experiences of the world economic crisis have adopted necessary measures for cautious fiscal policies (Berrittella and Zhang, 2015).

National culture and traditions also play an important role within the development of the EU Internal Market and together with the economic integration they influence the realisation of economic freedoms. On the one hand, the excessive preference of national culture and traditions would be in conflict with the European legislation, but on the other hand they have to be taken into consideration as a factor influencing the movement of economic freedoms (Hojnik, 2012).

A new type of barriers is created in the Digital Market when it comes buying and selling of goods and services online. The European Commission (2016c; 2016d) pointed out obstacles and deficiencies existing in e-commerce and regarding geo-blocking. In this sense, antidiscrimination measures are being circumvented and consumers or sellers are limited because of their belonging to a particular EU Member State. This was confirmed also by a research focused on the existence of territorial restrictions in the EU Member States in cross-border purchasing, according to which 63 per cent of all online purchases were in different stages of the purchase made impossible because of geo-blocking (European Commission, 2016e).

Barriers to the free movement exist in all economic freedoms (Egan and Guimarăes, 2012). Existing barriers within economic freedoms were identified by the European Commission but also by several authors.

Barriers to the free movement of goods were specified by Bourdet and Persson (2012), Guimarăes and Egan (2014), Hafner, Robin and Hoorens (2014); barriers to the free movement of services were pointed out by Canoy and Smith (2008), Egan and Guimarăes (2012), Hojnik (2012), Howarth and Sadeh (2010), Jacobsson (2013), Kasman and Turgutlu (2011), Kerneis and Prentice (2011), Lee (2013), Pelkmans and Mustilli (2014); barriers to the free movement of capital were 
analysed by Bröhmer (2007), Ringe (2010), Robin-Olivier (2012) and barriers to the free movement of persons were noted by Bartz and Fuchs-Schündeln (2012), Caragliu et al. (2013), Kovacs et al. (2014), van Riemsdijk (2013).

\section{Barriers to the free movement of goods}

Guimarăes and Egan (2014) identified technical and administrative obstacles as the main barriers to the free movement of goods, which are most frequent in the food trade. According to Bourdet and Persson (2012) administrative obstacles remain in the EU Internal Market in the form of trade procedures. The majority of quantitative restrictions to the free movement of goods in the EU Internal Market have been removed, as for example import quotas and export restrictions. Nontariff barriers to the free movement of goods in the EU Internal Market, in the form of technical standards limiting the trade, were also eliminated. Administrative barriers, however, are most visible in trading across-borders and according to the research carried out by Bourdet and Persson (2012) there are substantial differences between the EU Member States regarding delays in crossborder trade. Subsequently, the importer is supplying goods in to the EU Internal Market, but the length of the import procedure varies depending on the recipient country. According to the Doing Business 2015 report the administrative process can take five days in Cyprus, Denmark and Estonia up to 19 days in Hungary, 18 days in Italy and 17 days in Czech Republic (World Bank, 2014).

After a change in methodology in the 2016 Doing Business report, when taking into consideration only auto parts as a homogenous product regarding the import process (World Bank, 2015), the above mentioned differences between the EU Member States have to be reanalysed. However, even after specifying the analysis, still differences in terms of time remain and the EU Member States although as a part of the EU Internal Market, show differences when dealing with importing goods across borders. The latest 2019 Doing Business report shows that even if the overall trade across borders has become faster and easier, some of the EU Member States maintained obstacles in importing goods. Obtaining documents, preparing documents, processing documents, presenting documents and submitting documents can take up to 36 hours in Belgium. Other EU Member States can deal with it within one or two hours. Customs clearance and inspection procedures conducted by other official agencies were reported as activities, which can take up to 48 hours in Belgium, 24 hours in Ireland and 15 hours in Cyprus. Any other EU Member 
State dealt with such activities within a maximum of three hours (World Bank, 2019a; World Bank, 2019b).

Persisting administrative barriers to the free movement of goods were identified also by The European Commission, which according to the press release from $26^{\text {th }}$ February 2015 referred Germany to the Court of Justice of the EU because its national legislation does not comply with EU law. The European Commission pointed out the additional administrative obstacles in the form of requirements for notification of pyrotechnic articles and of their user manuals to the relevant government authority in Germany, despite the fact that the manufacturer fulfilled all necessary conditions in an another EU Member State (European Commission, 2015c). Hafner, Robin and Hoorens (2014) described administrative barriers and thereto linked other type of barriers in the context of an existing fragmentation and duplicity of product quality and safety requirements. Thus, additional administrative requirements often occur, because of newly adopted EU pieces of legislation regardless of previously existing national legislation. Administrative barriers can also cause linguistic barriers in cases where forms and documents are only available in the native language. In the case of companies trading across borders, the lack of harmonisation when dealing with administrative requirements leads to additional costs. The free movement of goods was according to the European Commission (2016d) limited also in Slovakia and Portugal regarding unjustified restrictions on the export of medicines. The European Commission has in this regard sent reasoned opinion in May 2016 and requested Slovakia and Portugal to remove unjustified obstacles to the free movement of goods.

\section{Barriers to the free movement of services}

Based on the heterogeneity of economic activities in the services sector, the existing barriers to the free movement of services are complex as well (Egan and Guimarăes, 2012). By using the example of professional services, Kerneis and Prentice (2011) have demonstrated the existence of legal, administrative and regulatory barriers, which affect service providers in the EU, but also which mainly limit service providers originating outside of the EU Internal Market. Jacobsson (2013) also noted the existence of administrative barriers to the free movement of services. In addition to existing legal barriers, Pelkmans and Mustilli (2014) highlighted an important group of intangible barriers, that are only little or not at all linked to the EU regulations, policies and legislation. They have introduced language and culture, networking and trust, local 
nature of some services and asymmetric information as these intangible barriers. Canoy and Smith (2008) stresses, that they cause a permanent heterogeneity in regards to the language and cultural barriers and that they can therefore be understood as legitimate barriers.

Pelkmans and Mustilli (2014) identified legal barriers as barriers in acquis in relation to the Services Directive, public procurement, infrastructure, financial services, professional services, security services and hazard, cross-cutting services. In this sense the Services Directive requires an in-depth analysis of the state of implementation, detailed monitoring with regards to the services providers and services consumers. In the case of the European public procurement is a potential improvement possible through a harmonisation of processes and remedies, which are still EU Member States’ national competence. Deficiencies in network industries, as for example railways, electronic communications, electronic frequencies and air traffic control, can be removed by appropriate incentives for supporting cross-border networks. This is only possible, however, if EU Member States' approaches take into account the needs of the EU Internal Market in services rather than just defending national competences, public and private financing of EU-wide networks. Barriers to financial services are associated with a persistent fragmentation, which is influenced by the obstacles to access retail banking services, mortgages, cross-border mergers and by missing instruments to ensure a stable financial system. Professional services are regulated mainly on national level, with a harmonization only in health care profession. Security services, gambling and cross-cutting services in retail, digital single market and logistic services are in terms of a legislative harmonization characterized by fragmentation and national specifics.

Except for legal barriers characteristic by a missing legislation the free movement of services in the EU Internal Market is limited also by deficiencies in transposition of the European legislation on national level. According to the July 2016 edition of the Single Market Scoreboard 35 of the total 732 infringements in the EU in 2015 were related to services. The average duration of these cases dealing with infringements in services was 37.8 months in EU average. Deficiencies in transposition of the EU legislation related to services have been the case in $18 \mathrm{EU}$ Member States. When taking into account also other areas analysed by the Single Market Scoreboard, for example service sectors such as air transport - 82 cases, health and consumers - 20 cases, road and rail transport - 45 cases, transport safety - 42 cases, which all are as such service related activities, the overall number of infringements in services in 2015 would reach 189 (European Commission, 2016f). 
As administrative barriers Kerneis and Prentice (2011) specified the additional restricting measures in EU Internal Market access for the non-EU professional service providers in the form of additional licences and permits, the need for approval of professional qualifications by a competent authority and lack of transparency in economic needs tests. Restrictions in providing services across borders are according to the European Court of Auditors (2016) apparent specifically when online purchasing, when the seller refers the customer from another EU Member State to a domestic seller with different terms and conditions of sale.

Because of new administrative barriers, the European Commission initiated in 2015 infringement procedures against Germany in the case of introducing minimum wages in transport services within Germany. The European Commission objected to such a regulation of minimum wages, because of its negative and disproportionate impacts on the freedom to provide services as well as on the free movement of goods in the EU Internal Market. Germany has not restricted the provision of services by foreign service providers on national territory but introduced new administrative barriers in this case. Foreign transport services providers would have a reporting obligation against customs authorities in Germany in the form of administrative forms provided by the German customs authorities. Furthermore, a refusal to pay minimum wages according to the German law will result in sanctions (European Commission, 2015h).

Pelkmans and Mustilli (2014) indicated language barriers as a factor often underestimated, which significantly impact the engagement of companies in cross-border contracts and public procurements though. By using the example of rail transport services, Pelkmans and Mustilli (2014) and Howarth and Sadeh (2010) stated the effects of language as a limiting barrier, reflected in the necessity to fulfil strict language preconditions for train drivers and in the exchange of train board staff on the EU Member States' borders. The train transport example has also a wider context, because it concerns the free movement of persons, recognition of qualifications and in the end social security and wages matters.

Despite the intended removal of existing obstacles to the free movement of services, the language barriers have not been clearly addressed by the Services Directive. The use of language is mentioned in the Services Directive on several occasions and in several contexts. In the introduction of the Services Directive the use of a clear and unambiguous language is stressed out in section 50 and the non-interference of provisions considering the points of single contact with the use of official languages in section 52 and section 60. The main text of the Services Directive 
enshrined the use of a plain and intelligible language in article seven, section two; provision of information in a clear and unambiguous manner in article seven, section three; realisation of measures in the EU Member States to provide information in several languages, but with no interference what so ever on the use of the official languages and thus this only positively encourages EU Member States in article seven, section five.

Cultural barriers and barriers in tradition reflect national specifics and national traditions of each EU Member State. Liberalisation within the EU Internal Market in this regard limits some of the cultural and national specifics. Restrictions on opening hours and on the retail sale of some types of goods such as alcoholic products in some EU Member States are thus equally affecting the citizens of the respective EU Member State, but also the potential customers from other EU Member States, e.g. in the case of services providers from another EU Member State (Hojnik, 2012). Restriction to the free movement of services by a cultural barrier can for example limit a service provider residing in Slovakia, who provides services also in Hungary. Provision of services in Hungary will have to be in accordance with the national legislation of Hungary, even though the traditions in Slovakia may be different to those in Hungary. This is the case when considering the opening hours of retail stores on Sundays. An influence of culture on the opening hours in retail was stressed out also by Howarth and Sadeh (2010).

Cultural effects in relation to religion were highlighted by Lee (2013), who noted religion as a factor supporting the trade in services by the creation of institutional and network effects. 'These effects enhance trade in services more than trade in goods' (Lee, 2013, p. 1001). The importance of culture was also mentioned by Kasman and Turgutlu (2011) who in the context of insurance services considered the culture as an essential factor impacting the EU Internal Market's creation.

In relation to electronic services the European Commission (2015j) noted the impact of trust as a barrier limiting the retail cross-border sale, whereby even though 50 per cent of the EU inhabitants buy online, only five per cent of companies in EU retail sell across borders.

\section{Barriers to the free movement of capital}

Barriers to the free movement of capital can according to Robin-Olivier (2012) have the form of restrictions in investing outside of an EU Member State. Robin-Olivier explained this by using the example of the Fiat company during the world economic crisis and the collective 
negotiations between the company and employee representatives. A company that would commit to stay in a concrete EU Member State and thereby retain jobs, in exchange for concessions in rights and requirements of the employees, would act contrary to the application of the free movement of capital. The focus on individual interests of the Fiat company and of the employees, on local or national government interests, cannot be considered as in accordance with provisions of the Treaty on the Functioning of the EU. Ringe (2010) in this regard stated, that the Court of Justice of the EU has not provided unified case law concerning the free movement of capital, because private companies are only occasionally subject to the free movement of capital requirements and vice versa state measures are almost always related to the free movement of capital. The free movement of capital can be limited also through a disproportionate state intervention, which would limit incoming investments into strategic companies by using a maximal share in this company, whereby only the Court of Justice of the EU could state the compliance of such measures with the EU primary law provisions on the protection of national interests (Bröhmer, 2007).

The existence of barriers to the free movement of capital was also stated by the European Commission (2015e), which according to the press release from $29^{\text {th }}$ April 2015 initiated infringements procedures against Latvia. The European Commission objected to the Latvian national legislation, which would require from the potential buyers of agricultural land from another EU Member States to meet the required professional qualifications of staff and the lack of tax arrears. Also Bulgaria, Hungary and Slovakia according to the European Commission's press release from 26 $6^{\text {th }}$ March 2015 (European Commission, 2015d) were asked to provide explanation of the compliance of national legislation in the field of agricultural land with provisions of the Treaty on the Functioning of the EU. The procedures of the European Commission in this regard were based on the assumption of a discriminatory treatment, which would include measures such as residence requirement in a given EU Member State, restrictions for persons without a local residence or without previous business activities in the territory, various restrictions based on missing professional knowledge, restrictions in ceding the use of land to another subject or requiring a prior approval of sales contracts. These requirements would then be contrary to the free movement of capital but also to the freedom of establishment. The European Commission considered the letter of formal notice as insufficient and requested Bulgaria, Hungary, Latvia and 
Slovakia on $26^{\text {th }}$ May 2016 to adjust their national legislation within two months in the form of reasoned opinion (European Commission, 2016c).

\section{Barriers to the free movement of persons}

Existing barriers to the free movement of persons were described by van Riemsdijk (2013) in relation with obstacles to the free movement of Polish nurses and that resulting from the efforts of some EU Member States to protect national labour market and because of non-recognition of qualifications, which is caused mainly due to national differences in education and training. Kovacs et al. (2014) identified administrative type mobility barriers in the context of administratively complicated and complex processes when obtaining licences and registrations of doctors. Caragliu et al. (2013) came to a conclusion, that the migration is influenced not only by the distance, but also by barriers of values, culture and formal institutes, which affect behavioural norms. According to Bartz and Fuchs-Schündeln (2012) the ongoing incompletion of labour mobility within the EU is caused by permanent barriers and not by national borders, the language differences being a permanent obstacle.

In the European Report on the Free Movement of Workers in Europe in 2012-13 the European Commission (2014) reported obstacles, which still exist in some EU Member States. Requirements on residence in a given EU Member State as a precondition for social benefits access, requiring language skills as a job prerequisite, access to study grants only for students from a particular EU Member State, possibility of employment in state administration only for the citizens of the concrete EU Member State or fulfilling strict national language knowledge were in this regard identified as main barriers. The European Commission (2015b) according to the press release from $26^{\text {th }}$ March 2015 has identified the existence of administrative barriers to the free movement of persons in the case of Belgium, where the proceedings were referred to the Court of Justice of the EU. Belgium was in this regard objected because it unilaterally refused to recognise documentation certifying the fulfilment of social security duties in another EU Member State. EU citizens temporarily working in Belgium or employed at the same time in several EU Member States are according to the EU legislation authorized to pay their social security only in one EU Member State and have to notify this to the other countries. Belgium decision to unilaterally require the payment of the social security contributions while refusing to recognize the payments made in another EU Member State failed to comply with EU law in this regard. According to the 
European Commission's press release from 29 th $^{\text {April }} 2015$ (European Commission, 2015f) actions on the Court of Justice of the EU were also undertaken against Hungary, which allows the access to notary profession only for national citizens. The Hungarian national legislation when requiring nationality in principle contradicted to the free movement of persons, but also the free movement of notary services and freedom of establishment.

Incompletion of the EU Internal Market is caused by the existence of barriers (overview of barriers see Annex 1) to the free movement in all four economic freedoms. Progress in the EU Internal Market's integration is different in economic freedoms, as for example higher in goods and smaller in services. Legal and administrative barriers are present in all four economic freedoms, and cultural and language barriers are more characteristic for the free movement of services. The future development regarding Brexit can also bring new political barriers to the entire EU Internal Market and consequently for all economic freedoms. In accordance to the existing barriers to the free movement of goods, Hafner, Robin and Hoorens (2014) have summarized, that it is unlikely for all barriers to be removed and that their elimination is a gradual process. Provided summary can be noted and transferred also onto the barriers to the free movement of services, capital and persons, respectively on the barriers of the entire EU Internal Market. The identification of existing barriers is a necessary precondition for their future mitigation.

\section{Internal or Single European Union Market}

The term EU Internal Market isn't used in the literature uniformly. Some authors (Altinisik, 2012, de Boer, 2013; Kosta, 2010; Lalanne, 2011; Lang, 2009, Terták, 2010); used the term internal market. Other authors (Bena and Jurajda, 2011; Edwards, 2008; Howarth and Sadeh, 2010; Choudhry, Jayasekera and Kling, 2014; Kasman and Turgutlu, 2011; Kawalec and Pytlarczyk, 2013; König and Ohr, 2013; Lockwood and Migali, 2009; Marques, 2010; TasanKok, 2013; Wagner, 2015) used exclusively the term single market. According to Kučerová (2010) the terms internal market and single market are used to highlight the degree of integration, unification of markets and removal of barriers. Monti (2010) has stated that from his perspective it is preferable to use the term single market in comparison with the term internal market. He reasoned this mainly because the citizens could understand the term internal market as binding to their own national country and not to the entire EU, further that from the non-EU countries' view 
the internal market could be seen as a market inwardly closed and last but not least that the term internal market does not give such a degree and feel of unification as the term single market does.

Synonymous understanding of the terms internal market and single market was used in the literature by several authors (Badinger and Maydell, 2009; Brännström, 2014, Buckley and Howarth, 2010; Buckley, Howarth and Quaglia, 2012; Canoy and Smith, 2008; de Bruijn, Kox and Lejour, 2008; Glachant and Ruester, 2014; Cherchye et al., 2007; Kerneis and Prentice, 2011; Nahuis, 2004; Norman, 1989; Notaro, 2011; Polanski, 2015; Quaglia, 2010; Rueda-Cantuche et al., 2013; Santagostino, 2012).

The European Commission uses primarily the term internal market, but there is no terminological unification in all areas. Based on the presentation of political priorities of J.C. Juncker as of a candidate for President of the European Commission from $15^{\text {th }}$ July 2014 (Juncker, 2014) the term single market was used in relation to the Digital Single Market. The composition of the European Commission 2014-19 proofed this terminological inconsistency when introducing the Commissioner for Internal Market, Industry, Entrepreneurship and SMEs and the Commissioner for Digital Single Market (European Commission, 2015a). The Treaty on EU and the Treaty on the Functioning of the EU are terminologically unified when using the term internal market.

Based on the terminological inconsistency, understanding of the internal market as of an uncompleted process and building on the identified barriers to the EU Internal Market in all four economic freedoms, the EU market can't be considered as single and fully uniform. Uniformity would indicate internal conformity, what given the on several occasions in this article identified barriers and differences between the EU Member States cannot be concluded. We are inclining therefore to the exclusive use of the term EU Internal Market, which better captures the essence of the current market consisting of 28 EU Member States.

\section{Conclusion}

The EU Internal Market isn't until today completed and it represents a process, in which completion in the short term can't be assumed. The EU Internal Market is a complex system, which includes the free movement of goods, services, capital and persons. All these subsystems are constantly changing because of economic, social, international and global influences. The EU Internal Market is therefore a living system that will never reach a full mobility of goods, services, 
capital and persons. The incompletion of the entire EU Internal Market is transferred also to the free movement of goods, services, capital and persons. Vice versa can be stated, that the EU Internal Market isn't functioning because the free movement of goods, services, capital and persons is not functioning.

The reason for the EU Internal Market's incompletion and of the limited mobility of economic freedoms is the existence of barriers. Barriers are considered as obstacles, limits or other similar measures, which hinder the free cross-border movement of goods, services, capital and persons in the EU Internal Market. Barriers can be caused by measures of the EU Member States, measures of specific businesses or they exist at the level of individuals. Barriers at the level of individuals are of a subjective nature and that is why they are persisting barriers and complicated to remove with EU or EU Member States interventions. Barriers to the entire EU Internal Market were identified, namely legal barriers, fiscal barriers, electronic barriers, barriers of culture and traditions, political barriers. Barriers to the entire EU Internal Market are affecting the free movement of all economic freedoms. Specific barriers to the free movement of goods, services, capital and persons were also identified, which don't affect the free movement of goods, services, capital and persons individually but they are all interlinked. Thus, barriers to the free movement of services can in this regard also represent barriers to the free movement of persons and the free movement of capital.

In this article identified and described today existing barriers to the entire EU Internal Market and barriers to the free movement of goods, services, capital and persons in the EU Internal Market are not considered as a list of all concrete existing barriers in the EU Internal Market, respectively of all concrete in the EU Internal Market indicating impacts of these barriers today. However, it is a complex view onto the barriers in the EU Internal Market considering all economic freedoms. Main types of barriers in the EU Internal Market and current barriers to the free movement of goods, services, capital and persons in the EU Internal Market were identified and described.

\section{References}

1. AidukienĖ, L. and KAZLAUSKiENĖ, V. (2012) International Trade in Services: Development Trends and Possibilities. Economics \& Management 17(4): 1315-1320. 
2. AltinişıK, U. (2012) Free Movement of Companies Within the EU. Ankara Bar Review 5(1): 99-117.

3. ARnold, J. M. and WÖRgÖTter, A. (2011) Structural reforms and the benefits of the enlarged EU internal market: still much to be gained. Applied Economics Letters 18(13): 1231-1235.

4. BADINGER, H. (2005) Growth Effects of Economic Integration: Evidence from the EU Member States. Review of World Economics 141(1): 50-78.

5. Badinger, H. and Maydell, N. (2009) Legal and Economic Issues in Completing the EU Internal Market for Services: An Interdisciplinary Perspective. Journal of Common Market Studies 47(4): 693-717.

6. Bachmann, V. and SidAwAy, J. D. (2016) Brexit geopolitics. Geoforum 77: 47-50.

7. BENA, J. and JURAJDA, Š . (2011) Financial Development and Corporate Growth in the EU Single Market. Economica 78(311): 401-428.

8. Berrittella, M. and Zhang, J. (2015) Fiscal sustainability in the EU: From the short-term risk to the long-term challenge. Journal of Policy Modeling 37(2): 261-280.

9. BARTZ, K. and FUCHS-SCHÜNDELN, N. (2012) The role of borders, languages, and currencies as obstacles to labor market integration. European Economic Review 56(6): 1148-1163.

10. Bluj, A. (2008) The influence of retirement systems on the free movement of persons in the European Union. Intereconomics 43(6): 371-376.

11. Bourdet, Y. and Persson, M. (2012) Completing the European Union Customs Union: The Effects of Trade Procedure Harmonization. Journal of Common Market Studies 50(2): 300314.

12. BRÄNNSTRÖM, L. (2014) Law, Objectives of Government, and Regimes of Truth: Foucault's Understanding of Law and the Transformation of the Law of the EU Internal Market. Foucault Studies 18: 173-194.

13. BRÖHMER, J. (2007) The Free Movement of Capital in the European Union and the Problem of 'Golden Shares' and Similar Instruments. Law in Context 25(2): 144-159.

14. Buckley, J. and Howarth, D. (2010) Internal Market: Gesture Politics? Explaining the EU's Response to the Financial Crisis. Journal of Common Market Studies 48: 119-141.

15. Buckley, J., Howarth, D. and Quaglia, L. (2012) Internal Market: The Ongoing Struggle to 'Protect' Europe from Its Money Men. Journal of Common Market Studies 50: 99-115. 
16. CAnoy, M. and Smith, P. M. (2008) Services and the Single Market'. Journal of Industry, Competition \& Trade 8(3/4): 319-347.

17. Caragliu, A. et al. (2013) Cultural determinants of migration. Annals of Regional Science 51(1): 7-32.

18. Carrera, S. (2005) What Does Free Movement Mean in Theory and Practice in an Enlarged EU? European Law Journal 11(6): 699-721.

19. Court of Justice of the European Union (2015) Annual Report 2014, Available from http://curia.europa.eu/jcms/upload/docs/application/pdf/2015-

04/en_ecj_annual_report_2014_pr1.pdf [Accessed 2 February 2016].

20. Court of Justice of the European Union (2016) Annual Report 2015, Available from http://curia.europa.eu/jcms/upload/docs/application/pdf/2016-

08/rapport_annuel_2015_activite_judiciaire_en_web.pdf [Accessed 25 November 2016].

21. DE BOER, N. J. (2013) Fundamental Rights and the EU Internal Market: Just how Fundamental are the EU Treaty Freedoms? A Normative Enquiry Based on John Rawls' Political Philosophy. Utrecht Law Review 9(1): 148-168.

22. DE Bruijn, R., KoX, H. and LeJOur, A. (2008) Economic benefits of an Integrated European Market for Services. Journal of Policy Modeling 30(2): 301-319.

23. Directive 2006/123/EC of the European Parliament and of the Council of 12 December 2006 on services in the internal market.

24. EDWARDS, T. H. (2008) Implicit trade Costs and European single market enlargement. Applied Economics 40(20): 2601-2613.

25. Egan, M. and Guimaraes, H. (2012) Compliance in the single market. Business \& Politics 14(4): 1-28.

26. European Commission (2012) Report from the Commission to the European Parliament, the Council, the European Central Bank, the European Economic and Social Committee, the Committee of Regions and the European Investment Bank. State of the Single Market Integration 2013. Contribution to the Annual Growth Survey 2013. COM(2012), 752 final, Available from http://eur-lex.europa.eu/legalcontent/EN/TXT/PDF/?uri=CELEX:52012DC0752\&qid=1472804668838\&from=EN [Accessed 16 February 2014]. 
27. European Commission (2014) European Report on the Free Movement of Workers in Europe in 2012-2013, Available from http://ec.europa.eu/social/BlobServlet?docId=13423\&langId=en [Accessed 13 June 2014].

28. European Commission (2015a) College (2014-2019). The Commissioners. The European Commission's political leadership, Available from http://ec.europa.eu/commission/20142019_en.

29. European Commission (2015b) Commission refers Belgium to Court for refusing certificates of workers affiliated in another Member State, Available from http://ec.europa.eu/social/main.jsp?langId=en\&catId=457\&newsId=2190\&furtherNews=yes

30. European Commission (2015c) Commission takes Germany to Court to remove trade barriers for pyrotechnic goods, Available from http://europa.eu/rapid/press-release_IP-154444_en.htm

31. European Commission (2015d) Financial Services: Commission opens infringement procedures against Bulgaria, Hungary, Lithuania and Slovakia on investor restrictions for agricultural land, Available from http://europa.eu/rapid/press-release_IP-15-4673_en.htm

32. European Commission (2015e) Financial Services: European Commission opens an infringement procedure against LATVIA on investor restrictions for agricultural land, Available from http://europa.eu/rapid/press-release_IP-15-4877_en.htm

33. European Commission (2015f) Internal Market: Nationality requirement for notaries: Commission takes HUNGARY to Court to ensure non-discrimination, Available from http://europa.eu/rapid/press-release_IP-15-4876_en.htm

34. European Commission (2015g) The Capital Markets Union: breaking down the barriers to completing the single market, Available from http://europa.eu/rapid/press-release_SPEECH15-4796_en.htm

35. European Commission (2015h) Transport: Commission launches infringement case on the application of the German Minimum Wage law to the transport sector, Available from http://europa.eu/rapid/press-release_IP-15-5003_en.htm

36. European Commission (2015i) Transport: driving Europe's economy forward, Available from http://europa.eu/rapid/press-release_SPEECH-14-253_en.htm

37. European Commission (2015j) Vice-President Ansip: Setting the scene for a Digital Single Market, Available from http://europa.eu/rapid/press-release_SPEECH-15-4937_en.htm 
38. European Commission (2016a) Boosting E-Commerce in the EU, Available from http://europa.eu/rapid/press-release_MEMO-16-1896_en.htm

39. European Commission (2016b) Commission proposes new e-commerce rules to help consumers and companies reap full benefit of Single Market, Available from http://europa.eu/rapid/press-release_IP-16-1887_en.htm

40. European Commission (2016c) Financial services: Commission requests Bulgaria, Hungary, Latvia, Lithuania, and Slovakia to comply with EU rules on the acquisition of agricultural land, Available from http://europa.eu/rapid/press-release_IP-16-1827_en.htm

41. European Commission (2016d) May infringements' package: key decisions, Available from http://europa.eu/rapid/press-release_MEMO-16-1823_en.htm

42. European Commission (2016e) Mystery shopping survey on territorial restrictions and geoblocking in the European Digital Single Market, Available from http://ec.europa.eu/consumers/consumer_evidence/market_studies/docs/geoblocking_final_re port_2016_en.pdf [Accessed 15 June 2016].

43. European Commission (2016f) Single Market Scoreboard. Infringements, Available from http://ec.europa.eu/internal_market/scoreboard/performance_by_governance_tool/infringeme nts/index_en.htm

44. European Commission (2016g) Single Market Scoreboard. Transposition, Available from http://ec.europa.eu/internal_market/scoreboard/performance_by_governance_tool/transpositi on/index_en.htm

45. European Court of Auditors (2016) Special Report. Has the Commission ensured effective implementation of the Services Directive?, Available from http://www.eca.europa.eu/Lists/ECADocuments/SR16_05/SR_SERVICES_EN.pdf [Accessed 2 June 2016].

46. Glachant, J.-M. and Ruester, S. (2014) The EU internal electricity market: Done forever? Utilities Policy 31: 221-228.

47. Guimaraes, H. and Egan, M. (2014) Barriers to Business in the Single Market, Available from http://ssrn.com/abstract=2399098

48. Hafner, M., Robin, E. and Hoorens, S. (2014) The Cost of Non-Europe in the Single Market. I - Free Movement of Goods, Brussels: European Union. 
49. Hojnik, J. (2012) The EU Internal Market and National Tradition and Culture: Any Room for Market Decentralisation? Croatian Yearbook of European Law \& Policy 8: 117-142.

50. HowARTH, D. and SADEH, T. (2010) The ever incomplete single market: differentiation and the evolving frontier of integration. Journal of European Public Policy 17(7): 922-935.

51. CHERCHYe, L. et al. (2007) One market, one number? A composite indicator assessment of EU internal market dynamics. European Economic Review 51(3): 749-779.

52. Choudhry, T., Jayasekera, R. and Kling, G. (2014) The Global Financial Crisis and the European Single Market: The end of integration. Journal of International Money \& Finance 49: 191-196.

53. Jacobsson, J. (2013) Liberalisation of Service Mobility in the EU's International Trade Agreements: As External as it Gets. European Journal of Migration \& Law 15(3): 245-261.

54. JunCKER, J.-C. (2014) A New Start for Europe: My Agenda for Jobs, Growth, Fairness and Democratic Change. Political Guidelines for the next European Commission. Opening Statement in the European Parliament Plenary Session, Available from http://ec.europa.eu/priorities/sites/beta-political/files/juncker-political-guidelines_en.pdf [Accessed 21 May 2015].

55. Kasman, A. and Turgutlu, E. (2011) Performance of European insurance firms in the single insurance market. International Review of Applied Economics 25(3): 363-378.

56. Kawalec, S. and PytlarczyK, E. (2013) Controlled Dismantlement of the Eurozone: A Strategy to Save the European Union and the Single European Market. German Economic Review 14(1): 31-49.

57. Kelemen, R. D., Menon, A. and Slapin, J. (2014) Wider and deeper? Enlargement and integration in the European Union. Journal of European Public Policy 21(5): 647-663.

58. Kerneis, P. and Prentice, J. (2011) The European Union as a market for professional services. Australian Journal of International Affairs 65(4): 436-453.

59. KNUdSEN, J. S. (2005) Is the Single European Market an Illusion? Obstacles to Reform of EU Takeover Regulation. European Law Journal 11(4): 507-524.

60. KostA, V. (2010) Internal Market Legislation and the Private Law of the Member States. The Impact of Fundamental Rights. European Review of Contract Law 6(4): 409-436. 
61. Kostadinova, V. (2013) The European Commission and the Configuration of Internal European Union Borders: Direct and Indirect Contribution. Journal of Common Market Studies 51(2): 264-280.

62. KovaCs, E. et al. (2014) Professional Issues. Licensing procedures and registration of medical doctors in the European Union. Clinical Medicine 14(3): 229-238.

63. KÖNIG, J. and OHR, R. (2013) Different Efforts in European Economic Integration: Implications of the EU Index. Journal of Common Market Studies 51(6): 1074-1090.

64. KUČEROVÁ, I. (2010) Hospodářské politiky v kontextu vývoje Evropské unie, Praha: Univerzita Karlova v Praze, Nakladatelství Karolinum.

65. Lalanne, S. (2011) Posting of workers, EU enlargement and the globalization of trade in services. International Labour Review 150(3-4): 211-234.

66. LANG, I. G. (2009) Patient mobility in the European Union: pushing for EU internal health market. Medicine And Law 28(4): 661-671.

67. LEe, Ch. W. (2013) Does religion affect international trade in services more than trade in goods? Applied Economics Letters 20(10): 998-1002.

68. Levent, K. (2009) Free Movement of Services (and the Liberalisation of Maritime Service Sector) in the European Union (EU): Limits of Institutional Steps from Above. Analele Universitatii Maritime Constanta 10(12): 69-82.

69. Lockwood, B. and Migali, G. (2009) Did The Single Market Cause Competition in Excise Taxes? Evidence From EU Countries. Economic Journal 119(536): 406-429.

70. Marques, H. (2010) Migration Creation and Diversion in the European Union: Is Central and Eastern Europe a 'Natural' Member of the Single Market for Labour? Journal of Common Market Studies 48(2): 265-291.

71. Martinoia, M. (2011) European Integration, Labour Market Dynamics and Migration Flows. European Journal of Comparative Economics 8(1): 97-127.

72. Monti, M. (2010) A New Strategy for the Single Market at the Service of Europe's Economy and Society. Report to the President of the European Commission José Manuel Barroso, Available

from http://ec.europa.eu/internal_market/strategy/docs/monti_report_final_10_05_2010_en.pdf [Accessed 13 February 2014]. 
73. NAHUIS, R. (2004) One size fits all?: Accession to the internal market; an industry-level assessment of EU enlargement. Journal of Policy Modeling 26(5): 571-586.

74. Norman, V. (1989) EFTA and the internal European market. Economic Policy 4(2): 423-465.

75. Notaro, G. (2011) European Integration and Productivity: Exploring the Early Effects of Completing the Internal Market. Journal of Common Market Studies 49(4): 845-869.

76. PaIn, N. and Young, G. (2004) The macroeconomic impact of UK withdrawal from the EU. Economic Modelling 21(3): 387-408.

77. Palmer, T. J. (1989) A Common Market in Financial Services--Practical Possibility or Unattainable Ideal. European Business Journal 1(3): 19-28.

78. РАтомÄKI, H. (2017) Will the EU Disintegrate? What Does the Likely Possibility of Disintegration Tell About the Future of the World. Globalizations 14(1): 168-177.

79. Pelkmans, J. (2012) Mutual Recognition: economic and regulatory logic in goods and services. Bruges European Economic Research (BEER) Papers 24/June 2012, Available from http://aei.pitt.edu/58617/1/beer15_(24).pdf [Accessed 18 May 2015].

80. Pelkmans, J. and Mustilli, F. (2014) The Cost of Non-Europe in the Single Market. II The Single Market for Services, Brussels: European Union.

81. PolAnski, P. P. (2015) Towards the single digital market for e-identification and trust services. Computer Law \& Security Review 31(6): 773-781.

82. Pungulescu, C. (2013) Measuring financial market integration in the European Union: EU15 vs. New Member States. Emerging Markets Review 17: 106-124.

83. Quaglia, L. (2010) Completing the single market in financial services: the politics of competing advocacy coalitions. Journal of European Public Policy 17(7): 1007-1023.

84. RĂvaș, O.-C. (2009) Free Movement Within the EU - a Fundamental Right. Annals of the University of Petrosani Economics 9(2): 237-244.

85. Ringe, W.-G. (2010) Company Law and Free Movement of Capital. Cambridge Law Journal 69(2): 378-409.

86. Robin-OliviER, S. (2012) Bargaining in the shadow of free movement of capital. European Review of Contract Law 8(2): 167-183.

87. Rueda-Cantuche, J. M. et al. (2013) The Single Market as an Engine for Employment through External Trade. Journal of Common Market Studies 51(5): 931-947. 
88. Santagostino, A. (2012) Permeability (Goods) and Impermeability (Services) in EU Internal Market: a Liberal Perspective. Eurolimes 13: 59-74.

89. TASAn-KoK, T. et al. (2013) Providing Cheap Land for Social Housing: Breaching the State Aid Regulations of the Single European Market. Regional Studies 47(4): 628-642.

90. Terták, E. (2010) The EU internal market for occupational pensions: Making further progress. Pensions: An International Journal 15(2): 140-147.

91. Trandafir, A. (2013) Tax Harmonization Measures at EU Level in the Corporate Tax Field. Contemporary Readings in Law \& Social Justice 5(2): 647-655.

92. Treaty on European Union (Consolidated version).

93. Treaty on the Functioning of the European Union (Consolidated version).

94. VAN RiEMSDIJK, M. (2013) Obstacles to the Free Movement of Professionals: Mutual Recognition of Professional Qualifications in the European Union. European Journal of Migration \& Law 15(1): 47-68.

95. Wagner, I. (2015) The Political Economy of Borders in a 'Borderless' European Labour Market. Journal of Common Market Studies 53(6): 1370-1385.

96. Welfens, P. J. J. (2016) Cameron's information disaster in the referendum of 2016: an exit from Brexit?. International Economics and Economic Policy 13(4): 539-548.

97. World Bank (2014) Doing Business 2015, Going Beyond Efficiency, Available from http://www.doingbusiness.org/ /media/WBG/DoingBusiness/Documents/AnnualReports/English/DB15-Full-Report.pdf [Accessed 28 November 2016].

98. World Bank (2015) Doing Business 2016, Measuring Regulatory Quality and Efficiency, Available from http://www.doingbusiness.org/ /media/WBG/DoingBusiness/Documents/AnnualReports/English/DB16-Full-Report.pdf [Accessed 28 November 2016].

99. World Bank (2019a) Trading Across Borders Methodology, Available from http://www.doingbusiness.org/en/methodology/trading-across-borders [Accessed 28 March 2019].

100. World Bank (2019b) Doing Business 2019, Training for Reform, Available from http://www.doingbusiness.org/content/dam/doingBusiness/media/AnnualReports/English/DB2019-report_web-version.pdf [Accessed 28 March 2019]. 


\section{Annex 1}

Barriers to the entire EU Internal market and to the economic freedoms

\begin{tabular}{|c|c|c|}
\hline $\begin{array}{c}\text { EU Internal } \\
\text { Market }\end{array}$ & Type of barriers & Author / authors \\
\hline \multirow{4}{*}{$\begin{array}{c}\text { Entire EU } \\
\text { Internal Market }\end{array}$} & Legal & $\begin{array}{l}\text { European Commission (2016g); Court of Justice of the European } \\
\text { Union (2015); Court of Justice of the European Union (2016) }\end{array}$ \\
\hline & Fiscal & Terták (2010); Howarth and Sadeh (2010); Trandafir (2013) \\
\hline & Culture & Hojnik (2012) \\
\hline & Electronic & $\begin{array}{l}\text { European Commission (2016c); European Commission (2016d); } \\
\text { European Commission (2016e) }\end{array}$ \\
\hline \multirow[b]{2}{*}{$\begin{array}{l}\text { Free movement } \\
\text { of goods }\end{array}$} & Technical & Guimarăes and Egan (2014); \\
\hline & Administrative & $\begin{array}{l}\text { Guimarăes and Egan (2014); Bourdet and Persson (2012); World Bank } \\
\text { (2014); World Bank (2019a); World Bank (2019b); European } \\
\text { Commission (2015c); Hafner, Robin and Hoorens (2014); European } \\
\text { Commission (2016d) }\end{array}$ \\
\hline \multirow{9}{*}{$\begin{array}{l}\text { Free movement } \\
\text { of services }\end{array}$} & Legal & $\begin{array}{l}\text { Kerneis and Prentice (2011); Pelkmans and Mustilli (2014); European } \\
\text { Commission (2016f) }\end{array}$ \\
\hline & Administrative & $\begin{array}{l}\text { Kerneis and Prentice (2011); Jacobsson (2013); European Court of } \\
\text { Auditors (2016); (European Commission, 2015h) }\end{array}$ \\
\hline & Regulatory & Kerneis and Prentice (2011) \\
\hline & Language & $\begin{array}{l}\text { Pelkmans and Mustilli (2014); Canoy and Smith (2008); Howarth } \\
\text { and Sadeh (2010) }\end{array}$ \\
\hline & Culture & $\begin{array}{l}\text { Pelkmans and Mustilli (2014); Canoy and Smith (2008); Hojnik } \\
\text { (2012); Howarth and Sadeh (2010); Lee (2013); Kasman and Turgutlu } \\
\text { (2011) }\end{array}$ \\
\hline & $\begin{array}{l}\text { Networking and } \\
\text { trust }\end{array}$ & Pelkmans and Mustilli (2014) \\
\hline & $\begin{array}{l}\text { Local nature of } \\
\text { services }\end{array}$ & Pelkmans and Mustilli (2014) \\
\hline & $\begin{array}{l}\text { Asymmetric } \\
\text { information }\end{array}$ & Pelkmans and Mustilli (2014) \\
\hline & Trust & European Commission $(2015 \mathrm{j})$ \\
\hline \multirow{3}{*}{$\begin{array}{l}\text { Free movement } \\
\text { of capital }\end{array}$} & $\begin{array}{l}\text { Investing } \\
\text { restrictions }\end{array}$ & Robin-Olivier (2012) \\
\hline & $\begin{array}{l}\text { State } \\
\text { interventions }\end{array}$ & Bröhmer (2007) \\
\hline & Legal & $\begin{array}{l}\text { European Commission (2015e); European Commission (2015d); } \\
\text { European Commission (2016c); }\end{array}$ \\
\hline \multirow{3}{*}{$\begin{array}{l}\text { Free movement } \\
\text { of people }\end{array}$} & Administrative & $\begin{array}{l}\text { Riemsdijk (2013); Kovacs et al. (2014); European Commission (2014); } \\
\text { European Commission (2015b); European Commission, 2015f }\end{array}$ \\
\hline & Culture & Caragliu et al. (2013) \\
\hline & Language & Bartz and Fuchs-Schündeln (2012); European Commission (2014) \\
\hline
\end{tabular}

Source: own elaboration 